3 Melcherite, trigonal $\mathrm{Ba}_{2} \mathrm{Na}_{2} \mathrm{Mg}\left[\mathrm{Nb}_{6} \mathrm{O}_{19}\right] \cdot 6 \mathrm{H}_{2} \mathrm{O}$, the 4 second natural hexaniobate, from Cajati, São Paulo, Brazil: Description and crystal structure

*E-mail: mabadean@terra.com.br 
26

Melcherite, ideally $\mathrm{Ba}_{2} \mathrm{Na}_{2} \mathrm{Mg}\left[\mathrm{Nb}_{6} \mathrm{O}_{19}\right] \cdot 6 \mathrm{H}_{2} \mathrm{O}$, occurs as a vug mineral in the carbonatite of the Jacupiranga mine, Cajati county, São Paulo state, Brazil, associated with dolomite, calcite, magnetite, pyrrhotite, tochilinite, "pyrochlore", and fluorapatite. This is also the type locality for zirkelite, quintinite, menezesite and pauloabibite. The mineral forms irregular, tabular crystals up to $200 \mu \mathrm{m}$ in maximum dimension. Melcherite is transparent and displays a vitreous lustre; it is beige with a white streak. It is non-fluorescent. The mineral displays perfect cleavage on $\{001\}$. Chemical composition varies from $\mathrm{Ba}_{2} \mathrm{Na}_{2} \mathrm{Mg}\left[\mathrm{Nb}_{6} \mathrm{O}_{19}\right] \cdot 6 \mathrm{H}_{2} \mathrm{O}$ to $(\mathrm{BaK})(\mathrm{NaCa}) \mathrm{Mg}\left[\mathrm{Nb}_{6} \mathrm{O}_{19}\right] \cdot 6 \mathrm{H}_{2} \mathrm{O}$. Empirical formulae for the first and the second compositions are: $\left(\mathrm{Ba}_{1.75} \mathrm{~K}_{0.19}\right)_{\Sigma 1.94}\left(\mathrm{Na}_{1.80} \mathrm{Ca}_{0.19}\right)_{\Sigma 1.99}\left(\mathrm{Mg}_{0.96} \mathrm{Mn}_{0.02} \mathrm{Al}_{0.02}\right)_{\Sigma 1.00} \mathrm{Nb}_{6.02} \mathrm{O}_{19.00} \cdot 6 \mathrm{H}_{2} \mathrm{O} \quad$ and $\left(\mathrm{Ba}_{0.99} \mathrm{~K}_{1.00}\right)_{\Sigma 1.99}\left(\mathrm{Na}_{1.02} \mathrm{Ca}_{0.96}\right)_{\Sigma 1.98}\left(\mathrm{Mg}_{0.95} \mathrm{Mn}_{0.05}\right)_{\Sigma 1.00} \mathrm{Nb}_{6.02} \mathrm{O}_{19.00} \cdot 6 \mathrm{H}_{2} \mathrm{O}$, respectively. Data for a single crystal with the second composition are: trigonal, $R \overline{3}, a=9.0117(6) \AA, c=$ 23.3986(16) $\AA, V=1645.64(19) \AA^{3}, Z=3$. Calculated density for this formula is $3.733 \mathrm{~g} / \mathrm{cm}^{3}$, and the calculated mean refractive index is 1.924 . Melcherite is a hexaniobate that has structural layers parallel to the xy plane that stack along the $c$-axis with simultaneous $1 / 3$ [1 -1 0] displacement so as to produce a $R$ lattice. The melcherite structure is built by layers of $\left[(\mathrm{Ba}, \mathrm{K})\left(\mathrm{O}, \mathrm{H}_{2} \mathrm{O}\right)_{9}\right]$ polyhedra and the $\left[\mathrm{Nb}_{6} \mathrm{O}_{19}\right]^{8-}$ super-octahedron (Lindqvist anion) interconnected by $\left[(\mathrm{Na}, \mathrm{Ca}) \mathrm{O}_{6}\right]$ polyhedra. $\mathrm{Mg}^{2+}$ cations are bonded to six water molecules each and are not associated with Lindqvist oxygen ions. The mineral is named in honour of Geraldo Conrado Melcher (1924-2011), a pioneer in Jacupiranga carbonatite studies. Both the description and the name were approved by the CNMNC-IMA (Nomenclature Proposal 2015018). Melcherite is the second natural hexaniobate. The first one is peterandresenite and the third is hansesmarkite.

KEYWORDS: Melcherite, new mineral, hexaniobate, crystal structure, chemical composition, Jacupiranga mine, Cajati, Brazil. 
Melcherite is the second natural hexaniobate. The first one is peterandresenite (Friis et al., 2014) and the third is hansesmarkite (Friis et al., 2016). Polyoxometalates of niobium are dominated by the Linqdvist hexaniobate ion, $\left(\mathrm{Nb}_{6} \mathrm{O}_{19}\right)^{8-}$, and its synthesis and stability requires alkaline conditions. The crystal structure of these compounds was first described by Lindqvist (1953). Hexaniobates are negatively charged clusters of six mutually edge-sharing $\mathrm{NbO}_{6}$ octahedra forming a super-octahedron (Nyman, 2011). Possible polyoxoniobate applications include their use as reagents in the break-down of nerve agents and in the development of filter media protection against chemical warfare agents (Kinnan et al., 2014). Polyoxometalates have also been investigated in coordination chemistry, leading to the development of hybrid organometallic hexametalates complexes (Abramov et al., 2016), and the synthesis of new polyoxoniobates coordinated to copper complexes (Wang et al., 2008).

The mineral is named in honour of Geraldo Conrado Melcher (1924-2011). He was professor at the Department of Mining Engineering at the Polytechnic School, University of São Paulo and was also a pioneer in Jacupiranga carbonatite studies (Melcher, 1966).

Both the description and name were approved by the CNMNC-IMA (Nomenclature Proposal 2015-018). Type material is deposited in the Museu de Geociências, Instituto de Geociências, Universidade de São Paulo, Rua do Lago, 562, 05508-080 - São Paulo, SP, Brazil. Specimen number: DR982. Part of the cotype sample has been deposited at the University of Arizona Mineral Museum, RRUFF Project (http://rruff.info/R130752). 4806'37"W), Cajati County, São Paulo, Brazil (Menezes Filho and Martins, 1984). For general information about this carbonatite please see Menezes Filho et al. (2015). This is also the type locality for zirkelite (Hussak and Prior, 1895), quintinite (Chao and Gault, 1997), menezesite (Atencio et al., 2008) and pauloabibite (Menezes Filho et al., 2015). Although the joint occurrence of menezesite, pauloabibite and melcherite has not been observed, these minerals may be genetically related. Pauloabibite is trigonal $\mathrm{NaNbO}_{3}$, isostructural with 
91 Kinomura et al. (1984) and Kumata et al. (1990) from a two-step synthesis method, involving 92 the preparation of $\mathrm{Na}_{8} \mathrm{Nb}_{6} \mathrm{O}_{19} \cdot 13 \mathrm{H}_{2} \mathrm{O}$ (a hexaniobate) followed by hydrothermal reaction with $93 \mathrm{NaOH}$ in a silver-lined vessel at $250{ }^{\circ} \mathrm{C}$. Menezesite is a heteropolyoxoniobate, $94(\square, \mathrm{Ba}, \mathrm{K})_{12}(\square, \mathrm{Mg})_{3} \mathrm{Zr}_{4}\left(\mathrm{BaNb}_{12} \mathrm{O}_{42}\right) \cdot 12 \mathrm{H}_{2} \mathrm{O}$, cubic (Atencio et al. 2008). According to Nyman 95 et al. (2002), the heteropolyanions of W, Mo, and V are formed simply by acidification of 96 solutions of their oxoanions. Under similar conditions, these oxoanion precursors are not 97 available for $\mathrm{Nb}$, and $\mathrm{Nb}$-oxo chemistry is dominated by formation of the Lindquist ion $98\left[\mathrm{Nb}_{6} \mathrm{O}_{19}\right]^{8-}$ (present in melcherite). However, heteropolyniobate (present in menezesite) 99 formation is favored in hydrothermal reactions of aqueous, alkaline precursor mixtures. A 100 competing phase to the formation of polyoxoniobates in hydrothermal aqueous reactions 101 involving $\mathrm{Nb}$ and an alkali hydroxide is $\mathrm{NaNbO}_{3}$, avoided by using short reaction times (i.e., 10224 hours or less) (Nyman et al., 2002). So melcherite could be originally formed, under acid 103 conditions, and posteriorly, under basic conditions, menezesite and pauloabibite formed.

104 Quintinite, menezesite, pauloabibite and melcherite occur in the so-called 105 "intermediate zone", characterized by a high dolomite and slightly anomalous pyrochlore 106 content. Associated minerals are dolomite, calcite, magnetite, pyrrhotite, tochilinite, 107 "pyrochlore", pyrite, and fluorapatite. Melcherite formed as a carbonatite vug mineral.

112 Melcherite forms irregular, tabular crystals up to $200 \mu \mathrm{m}$ in maximum dimension (Fig. 113 1). The mineral is transparent and displays a vitreous lustre; it is beige and the streak is white. 114 It is non-fluorescent under both short $(254 \mathrm{~nm})$ and long wavelength $(366 \mathrm{~nm})$ ultraviolet 115 radiation. The mineral displays perfect cleavage on $\{001\}$. Fracture was not determined. 116 Twinning and parting were not observed. The Mohs hardness and density were not measured 117 due to the paucity of material but the calculated density is $3.733 \mathrm{~g} / \mathrm{cm}^{3}$ [based on the empirical 118 formula $\left.\left(\mathrm{Ba}_{0.99} \mathrm{~K}_{1.00}\right)_{\Sigma 1.99}\left(\mathrm{Na}_{1.02} \mathrm{Ca}_{0.96}\right)_{\Sigma 1.98}\left(\mathrm{Mg}_{0.95} \mathrm{Mn}_{0.05}\right)_{\Sigma 1.00} \mathrm{Nb}_{6.02} \mathrm{O}_{19.00} \cdot 6 \mathrm{H}_{2} \mathrm{O}\right]$. Refractive 119 indices were not measured due to paucity of material. The mean refractive index is estimated 120 as 1.924 using the Gladstone-Dale relationship.

121 

electron images, we can see that the crystals are zoned (Fig. 2). The chemical analyses (Table

128 1) were done by means of a Cameca SX100 electron microprobe (WDS mode, $15 \mathrm{kV}, 10 \mathrm{nA}$, $12920 \mu \mathrm{m}$ beam diameter). $\mathrm{H}_{2} \mathrm{O}$ was inferred from the crystal structure determination of 130 melcherite. $\mathrm{H}_{2} \mathrm{O}$ was initially assumed by difference prior to the matrix correction (PAP) and 131 then calculated by stoichiometry post matrix correction due to software limitations. Analyses 132 from the brighter areas of the melcherite crystal, (Fig. 2 backscattered electron image) have 133 the following composition:

$134\left(\mathrm{Ba}_{1.75} \mathrm{~K}_{0.19}\right)_{\Sigma 1.94}\left(\mathrm{Na}_{1.80} \mathrm{Ca}_{0.19}\right)_{\Sigma 1.99}\left(\mathrm{Mg}_{0.96} \mathrm{Mn}_{0.02} \mathrm{Al}_{0.02}\right)_{\Sigma 1.00} \mathrm{Nb}_{6.02} \mathrm{O}_{19.00} \cdot 6 \mathrm{H}_{2} \mathrm{O}$ (mean of 4 point 135 analyses). Those from the darker areas correspond to $136\left(\mathrm{Ba}_{0.99} \mathrm{~K}_{1.00}\right)_{\Sigma 1.99}\left(\mathrm{Na}_{1.02} \mathrm{Ca}_{0.96}\right)_{\Sigma 1.98}\left(\mathrm{Mg}_{0.95} \mathrm{Mn}_{0.05}\right)_{\Sigma 1.00} \mathrm{Nb}_{6.02} \mathrm{O}_{19.00} \cdot 6 \mathrm{H}_{2} \mathrm{O} \quad$ (mean of 8 point 137 analyses). The enrichment in $\mathrm{Ba}$ is coupled to the enrichment in $\mathrm{Na}$ and depletion of $\mathrm{K}$ and 138 Ca. The analyses were obtained in points of several shades of gray observed in backscattered electron images distributed in different crystals. These analyses were ordered in ascending Ba apfu numbers, numbered from 1 to 25 , and served as the basis for the construction of the graph of Figure 3. $(\mathrm{BaK})(\mathrm{NaCa}) \mathrm{Mg}\left[\mathrm{Nb}_{6} \mathrm{O}_{19}\right] \cdot 6 \mathrm{H}_{2} \mathrm{O}$. Coupled heterovalent substitutions at two sites are verified.

144 As discussed by Hatert and Burke (2008), where a heterovalent substitution occurs at a given 145 crystallographic site, the charge balance can also be maintained by coupling this substitution 146 to another heterovalent substitution at a different site. At the $\mathrm{Ba}$ site, the atom $\mathrm{Ba}^{2+}$ is 147 progressively replaced by $\mathrm{K}^{+}$, and to maintain charge balance, the atom $\mathrm{Na}^{+}$is progressively 148 replaced by $\mathrm{Ca}^{2+}$ at the $\mathrm{Na}$ site. The substitution mechanism is $\mathrm{Ba}^{2+}+\mathrm{K}^{+} \leftrightarrow \mathrm{Na}^{+}+\mathrm{Ca}^{2+}$. The 149 boundary site-occupancies between the two members of the series is $150(\mathrm{BaK})(\mathrm{NaCa}) \mathrm{Mg}\left[\mathrm{Nb}_{6} \mathrm{O}_{19}\right] \cdot 6 \mathrm{H}_{2} \mathrm{O}$. We could imagine a solid solution series from $151 \mathrm{Ba}_{2} \mathrm{Na}_{2} \mathrm{Mg}\left[\mathrm{Nb}_{6} \mathrm{O}_{19}\right] \cdot 6 \mathrm{H}_{2} \mathrm{O}$ to $\mathrm{K}_{2} \mathrm{Ca}_{2} \mathrm{Mg}\left[\mathrm{Nb}_{6} \mathrm{O}_{19}\right] \cdot 6 \mathrm{H}_{2} \mathrm{O}$, with two mineral species, but the 152 composition varies only from the first end-member to the intermediate member. As no 153 analyses correspond to predominant $\mathrm{K}$ and $\mathrm{Ca}$, only one mineral species is defined.

154 The formula $\mathrm{BaCa}_{2} \mathrm{Mg}\left[\mathrm{Nb}_{6} \mathrm{O}_{19}\right] \cdot 6 \mathrm{H}_{2} \mathrm{O}$ (Andrade et al., 2015) is incorrect because $\mathrm{Na}$ 155 was not identified. The change in formula was previously approved executively by CNMNC 156 IMA Newsletter No. 29 (Hålenius et al., 2016): "Soon after the approval of the new mineral 
melcherite (IMA No. 2015-018; see CNMNC Newsletter 25), the authors of the proposal have communicated results of subsequent analytical work on this mineral, which verifies essential contents of sodium. The new data were examined carefully by the CNMNC officers and were found reliable. The revised simplified formula, $\mathrm{Ba}_{2} \mathrm{Na}_{2} \mathrm{Mg}\left[\mathrm{Nb}_{6} \mathrm{O}_{19}\right] \cdot 6 \mathrm{H}_{2} \mathrm{O}$, has been approved executively."A fragment of the darker part was extracted from the polished section for crystal structure determination.

\section{Crystal structure determination}

166

167

168

169

170

171

172

173

174

175

176

177

178

179

180

181

182

183

184

185

186

187

188

Powder X-ray diffraction data (XRD) were obtained using a Siemens D5000 diffractometer equipped with a Göbel mirror and a position-sensitive detector using $\mathrm{CuK \alpha}$ radiation and $40 \mathrm{kV}$ and $40 \mathrm{~mA}$ at the Instituto de Geociências of the Universidade de São Paulo (Table 2). Unit cell parameters refined from the powder data are as follows: Trigonal, Space Group: $R \overline{3}, a=9.022(2) \AA, c=23.410(6) \AA, V=1650.2(8) \AA^{3} \quad, Z=3$.

A single-crystal X-ray study was carried-out using a Bruker APEX II CCD diffractometer with graphite-monochromated $\operatorname{MoK\alpha }(\lambda=0.71073 \AA)$ radiation and gave the following data: Trigonal, Space Group: $R \overline{3}, a=9.0117(6) \AA, c=23.3986(16) \AA, c: a=$ 2.5965, $V=1645.64(19) \AA^{3}, Z=3$. The X-ray absorption correction was applied to intensity data using the program SADABS from Bruker.

The SHELXL-97 package (Sheldrick, 2008) was used for the direct methods structure solution and its subsequent refinement. The $\mathrm{Ba}$ and $\mathrm{Na}$ sites were refined assuming full but joint occupation by $\mathrm{Ba} / \mathrm{K}$ and $\mathrm{Na} / \mathrm{Ca}$ respectively, which yielded occupancy values close to those indicated by the empirical formula based on the EMP analysis. A final difference Fourier synthesis allowed the $\mathrm{H}$ atom positions of the water molecule to be located, which were then refined with soft restraints of $0.86 \AA$ on the $\mathrm{O}-\mathrm{H}$ distances and $1.40 \AA$ on the $\mathrm{H}-\mathrm{H}$ distance, and with $U_{\text {iso }}$ values fixed at $\sim 1.5$ times that of the $\mathrm{O}$ atom. Refinement of this final model converged to an R1 of 0.017 and the crystal chemical formula obtained is $\left(\mathrm{Ba}_{1.06} \mathrm{~K}_{0.94}\right)\left(\mathrm{Na}_{1.09} \mathrm{Ca}_{0.91}\right) \mathrm{Nb}_{6} \mathrm{Mg}\left[\mathrm{O}_{18.98}(\mathrm{OH})_{0.02}\right]_{\Sigma 19.00}$, where a small fraction of the oxygen atoms in the hexaniobate polyanion is assumed to be replaced by $\mathrm{OH}$ groups in order to balance the slight positive charge deficiency associated with the $\mathrm{Ba} / \mathrm{K}$ and $\mathrm{Na} / \mathrm{Ca}$ sites. $6 \mathrm{H}_{2} \mathrm{O}$. Details of the data collection and structure refinement are given in Tables 3 and 4. Selected 
189 bond distances and associated bond -valence sum calculations, using the parameters of Brese and O'Keefe (1991), are given in Table 5.

Melcherite is a hexaniobate that has structural layers parallel to the xy plane that stack along the $c$-axis with simultaneous $1 / 3\left[\begin{array}{lll}1 & -1 & 0\end{array}\right]$ displacement so as to produce a $R$ lattice.

193 The melcherite structure (Figs. 4 and 5) is built by layers of $\left[(\mathrm{Ba}, \mathrm{K})\left(\mathrm{O}, \mathrm{H}_{2} \mathrm{O}\right)_{9}\right]$ polyhedra and 194 the $\left[\mathrm{Nb}_{6} \mathrm{O}_{19}\right]^{8-}$ super-octahedron (Lindqvist anion) interconnected by $\left[(\mathrm{Na}, \mathrm{Ca}) \mathrm{O}_{6}\right]$ polyhedra 195 There is a significant distortion present in the $\mathrm{Nb}-\mathrm{O}$ octahedron forming the hexaniobate 196 polyanion, as measured by the octahedral angle variance (OAV), 113.650, and quadratic 197 elongation (OQE), 1.040, indices (Robinson et al. 1971). The results are comparable to the

$198 \mathrm{NbO}_{6}$ octahedra present in the crystal structure of peterandresenite and hansesmarkite (Table 199 6). $\mathrm{Ba} / \mathrm{K}$ is coordinated by six oxygens and three water molecules. The $\mathrm{Na} / \mathrm{Ca}$ is coordinated 200 by six oxygen atoms in a distorted octahedron and the OAV and OQE values are 354.100 and 201 1.113, respectively. $\mathrm{Mg}^{2+}$ cations are bonded to six water molecules each and are not 202 associated with Lindqvist oxygen ions. The comparison with $\mathrm{MnO}_{6}$ in peterandresenite and 203 hansesmarkite shows that the octahedral coordination of the $\mathrm{Mg}$ cation is relatively 204 undistorted, as indicated by the indice values of OAV, 12.285, and OQE, 1.003 (Table 6).

205 The mineral is structurally similar to the synthetic compounds $206 \mathrm{Cs}_{6} \mathrm{Na}_{2}\left(\mathrm{Nb}_{6} \mathrm{O}_{19}\right) \cdot 18 \mathrm{H}_{2} \mathrm{O}$ and $\mathrm{Rb}_{6}\left(\mathrm{H}_{2} \mathrm{Nb}_{6} \mathrm{O}_{19}\right) \cdot 19 \mathrm{H}_{2} \mathrm{O}$, studied by Nyman et al. (2006) (Table 7). 207 They have the same space group of melcherite, $R-3$. The unit cell dimensions and 208 arrangement of Lindqvist ion $\left[\mathrm{Nb}_{6} \mathrm{O}_{19}\right]^{8-}$ are very similar. The crystallographic parameters of melcherite are compared with those of the other hexaniobate minerals in Table 8.

210

211

\section{Acknowledgements}

213 We acknowledge the Sao Paulo Research Foundation for financial support (Grants: 214 2011/22407-0 and 2013/03487-8); the Principal Editor, Peter Williams, the reviewer Peter 215 Leverett and anonymous reviewers, and the members of the Commission on New Minerals 216 and Mineral Names of the International Mineralogical Association (CNMNC-IMA) for their 217 helpful suggestions and comments. 


\section{References}

222

223

224

225

226

227

228

229

230

231

232

233

234

235

236

237

238

239

240

241

242

243

244

245

246

247

248

249

250

251

252

Andrade, M.B., Atencio, D. and Menezes Filho, L.A.D. (2015) Melcherite, IMA 2015-018. CNMNC Newsletter No. 25, June 2015, page 547; Mineralogical Magazine, 79, 541547.

Abramov, P.A., Vicent, C., Kompankov, N.B., Gushchin, A.L. and Sokolov, M.N. (2016) Coordination of $\left\{\mathrm{C}_{5} \mathrm{Me}_{5} \mathrm{Ir}\right\}^{2+}$ to $\left[\mathrm{M}_{6} \mathrm{O}_{19}\right]^{8-}(\mathrm{M}=\mathrm{Nb}, \mathrm{Ta})-$ Analogies and Differences between $\mathrm{Rh}$ and Ir, $\mathrm{Nb}$ and Ta. European Journal of Inorganic Chemistry, 1, 154-160.

Atencio, D., Coutinho, J.M.V., Doriguetto, A.C., Mascarenhas, Y.P., Ellena, J.A. and Ferrari, V.C. (2008) Menezesite, the first natural heteropolyniobate, from Cajati, São Paulo, Brazil: Description and crystal structure. American Mineralogist, 93, 81-87.

Brese, N.E. and O'keeffe, M. (1991) Bond-valence parameters for solids. Acta Crystallographica Section B: Structural Science, 47(2), 192-197.

Chao, G.Y. and Gault, R.A. (1997) Quintinite-2H, quintinite-3T, charmarite-2H, charmarite$3 T$ and caresite-3T, a new group of carbonate minerals related to the hydrotalcitemanasseite group. Canadian Mineralogist, 35, 1541-1549.

Friis, H., Larsen, A.O., Kampf, A.R., Evans, R.J., Selbekk, R.S., Sánchez, A.A. and Kihle, J. (2014) Peterandresenite, $\mathrm{Mn}_{4} \mathrm{Nb}_{6} \mathrm{O}_{19} \bullet 14 \mathrm{H}_{2} \mathrm{O}$, a new mineral containing the Lindqvist ion from a syenite pegmatite of the Larvik Plutonic Complex, southern Norway. European Journal of Mineralogy, 26, 567-576.

Friis, H., Weller, M.T. and Kampf, A.R. (2016) Hansesmarkite, $\mathrm{Ca}_{2} \mathrm{Mn}_{2} \mathrm{Nb}_{6} \mathrm{O}_{19} \cdot 20 \mathrm{H}_{2} \mathrm{O}$, a new hexaniobate from a syenite pegmatite in the Larvik Plutonic Complex, southern Norway. Mineralogical Magazine (in press). DOI: https://doi.org/10.1180/minmag.2016.080.109

Hålenius, U., Hatert, F., Pasero, M. and Mills, S.J. (2016) New minerals and nomenclature modifications approved in 2015 and 2016. CNMNC Newsletter 29. Mineralogical Magazine, 80, 199-205,

Hatert, F. and Burke, E.A.J. (2008) The IMA-CNMNC dominant-constituent rule revisited and extended. Canadian Mineralogist, 46, 717-728.

Hussak, E. and Prior, G.T. (1895) Lewisite and zirkelite, two new Brazilian minerals. Mineralogical Magazine, 11, 80-88.

Kinnan, M.K., Creasy, W.R., Fullmer, L.B., Schreuder-Gibson, H.L. and Nyman, M. (2014) Nerve Agent Degradation with Polyoxoniobates. European Journal of Inorganic

This is a 'preproof' accepted article for Mineralogical Magazine.

This version may be subject to change during the production process.

https://10.1180/minmag.2017.081.026 
Chemistry, 2014(14), 2361-2367.

255 Kinomura, N., Kumata, N., and Muto, F. (1984) A new allotropic form with ilmenite-type 256 structure of $\mathrm{NaNbO}_{3}$. Materials Research Bulletin, 19, 299-304.

257 Kumata, N., Kinomura, N., and Muto, F. (1990) Crystal structure of ilmenite-type $\mathrm{LiNbO}_{3}$ 258 and $\mathrm{NaNbO}_{3}$. Journal of the Ceramic Society of Japan, 98, 384-388.

259 Lindqvist, I. (1953) The structure of the hexaniobate ion in $7 \mathrm{Na}_{2} \mathrm{O} \cdot 6 \mathrm{Nb}_{2} \mathrm{O}_{5} \cdot 32 \mathrm{H}_{2} \mathrm{O}$. Arkiv for 260

Menezes Filho, L.A.D., Atencio, D., Andrade, M.B., Downs, R.T., Chaves, M.L.S.C., 264 Romano, A.W., Scholz, R. and Persiano, A.I.C. (2015) Pauloabibite, trigonal $\mathrm{NaNbO}_{3}$, isostructural with ilmenite, from the Jacupiranga carbonatite, Cajati, São Paulo, Brazil. American Mineralogist, 100, 442-446.

Menezes Filho, L.A.D. and Martins, J.M. (1984) The Jacupiranga mine, São Paulo, Brazil. Mineralogical Record, 15, 261-270.

Nyman, M. (2011) Polyoxoniobate chemistry in the 21st century. Dalton Transactions, 40(32), 8049-8058.

Nyman, M., Alam, T.M., Bonhomme, F., Rodriguez, M.A., Frazer, C.S. and Welk, M.E. (2006) Solid-State structures and solution behaviour of alkali salts of the $\left[\mathrm{Nb}_{6} \mathrm{O}_{19}\right]^{8-}$ Lindqvist Ion. Journal of Cluster Science, 17, 197-219.

Nyman, M., Bonhomme, F., Alam, T.M., Rodriguez, M.A., Cherry, B.R., Krumhansl, J.L., Nenoff, T.M., and Sattler, A.M. (2002) A general synthetic procedure for heteropolyniobates. Science, 297, 996-998.

Wang J.P., Niu, H.Y. and Niu, J.Y. (2008) A novel Lindqvist type polyoxoniobate coordinated to four copper complex moieties: $\left\{\mathrm{Nb}_{6} \mathrm{O}_{19}\left[\mathrm{Cu}\left(2,2^{\prime}-\text { bipy }\right)\right]_{2}\left[\mathrm{Cu}\left(2,2^{\prime}-\right.\right.\right.$ bipy) $\left.]_{2}\right]_{2} \cdot 19 \mathrm{H}_{2} \mathrm{O}$. Inorganic Chemistry Communications, 11(1), 63-65. 
282 TABLE 1. Chemical composition of melcherite from the Cajati mine (in wt $\%$ ).

283 TABLE 2. X-ray powder diffraction data for melcherite.

284 TABLE 3. Structure refinement results for melcherite.

285 TABLE 4. Final fractional coordinates and displacement parameters of atoms in melcherite.

286 TABLE 5. Selected bond lengths and bond valences of the refined melcherite structure.

287 TABLE 6. Selected interatomic bond lengths $(\AA)$ and octahedral distortion indices for

288 melcherite $\left(\mathrm{Ba}_{2} \mathrm{Na}_{2} \mathrm{MgNb}_{6} \mathrm{O}_{19} \bullet 6 \mathrm{H}_{2} \mathrm{O}\right)$, peterandresenite $\left(\mathrm{Mn}_{4} \mathrm{Nb}_{6} \mathrm{O}_{19} \bullet 14 \mathrm{H}_{2} \mathrm{O}\right)$ and 289 hansesmarkite $\left(\mathrm{Ca}_{2} \mathrm{Mn}_{2} \mathrm{Nb}_{6} \mathrm{O}_{19} \cdot 20 \mathrm{H}_{2} \mathrm{O}\right)$.

290 TABLE 7. Comparative data for melcherite and synthetic compounds (all trigonal, $R-3$ ).

291 TABLE 8. Comparison of melcherite with other naturally-occurring hexaniobates. 
311 FIG. 1. Melcherite from the Cajati mine, São Paulo, Brazil.

312 FIG. 2. Backscattered electron image of melcherite.

313 FIG. 3. Chemical variability in melcherite.

314 FIG. 4. Crystal structure of melcherite. $(\mathrm{Ba}, \mathrm{K})=$ yellow; $(\mathrm{Na}, \mathrm{Ca})=$ pink; $\mathrm{Mg}=$ green; $\mathrm{Nb}=$ 315 blue; $\mathrm{O}=$ red and $\mathrm{OW}=$ grey.

316 FIG. 5. Lindquist polyanions $\left[\mathrm{Nb}_{6} \mathrm{O}_{19}\right]^{8-}$ stacking sequence in the crystal structure of 317 melcherite. 
This is a 'preproof' accepted article for Mineralogical Magazine.

This version may be subject to change during the production process.

https://10.1180/minmag.2017.081.026 


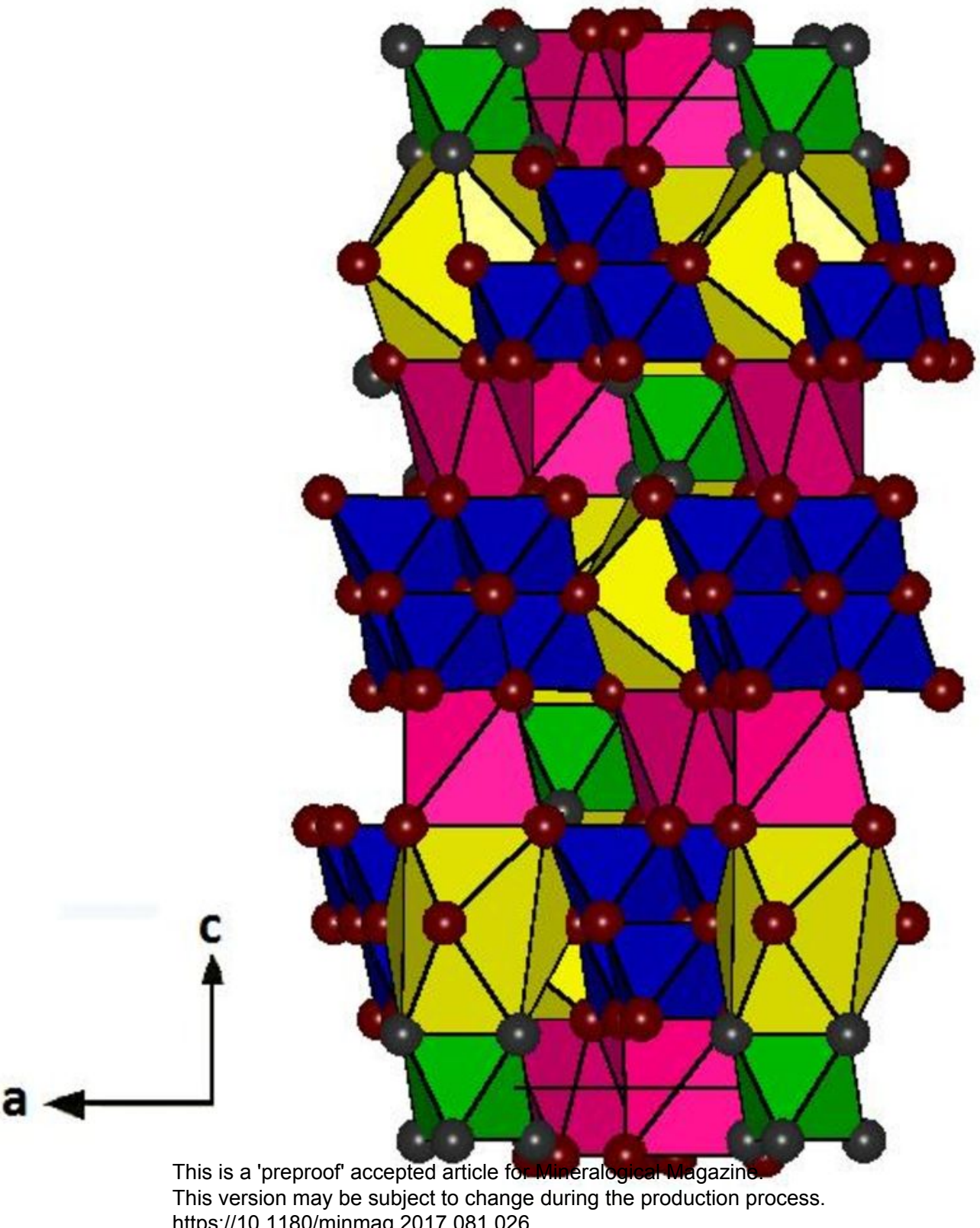



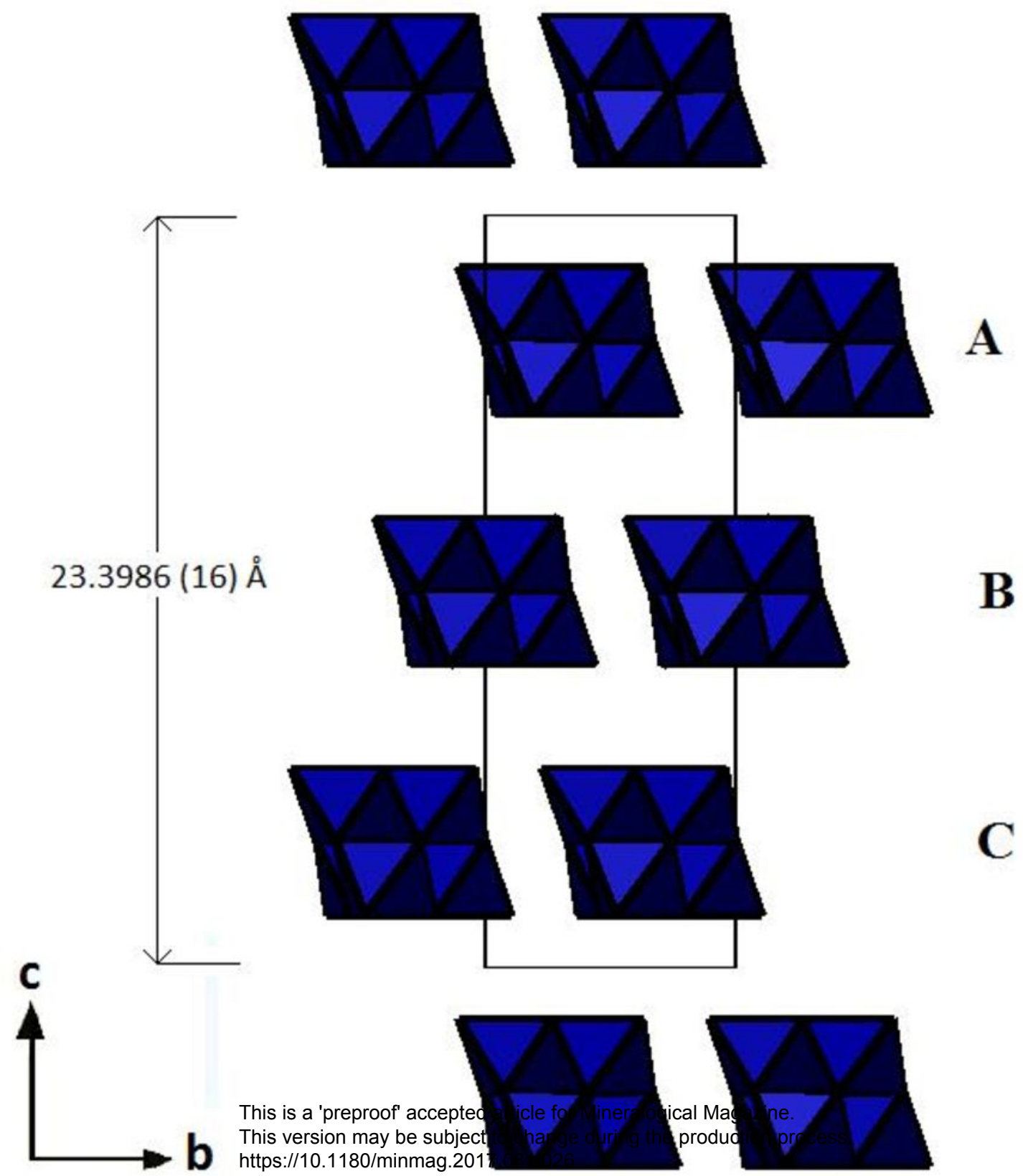
TABLE 1. Chemical composition of melcherite from the Cajati mine (in wt\%).

\begin{tabular}{llllllll}
\hline Constituent & 1 & Range & $\begin{array}{l}\text { Standard } \\
\text { deviation }\end{array}$ & Range & $\begin{array}{l}\text { Standard } \\
\text { deviation }\end{array}$ & Probe standard \\
\hline $\mathrm{K}_{2} \mathrm{O}$ & 0.70 & $0.61-0.89$ & 0.13 & 3.88 & $3.71-4.07$ & 0.14 & orthoclase jadeite \\
$\mathrm{Na}_{2} \mathrm{O}$ & 4.30 & $3.76-4.68$ & 0.42 & 2.60 & $2.41-2.76$ & 0.13 & barite \\
$\mathrm{BaO}$ & 20.66 & $20.29-20.92$ & 0.27 & 12.44 & $12.13-12.91$ & 0.29 & wollastonite \\
$\mathrm{CaO}$ & 0.83 & $0.70-0.97$ & 0.14 & 4.41 & $4.20-4.60$ & 0.16 & forsterite \\
$\mathrm{MgO}$ & 3.00 & $2.90-3.06$ & 0.08 & 3.15 & $3.07-3.23$ & 0.06 & pyrophanite \\
$\mathrm{MnO}$ & 0.09 & $0.06-0.13$ & 0.03 & 0.28 & $0.22-0.38$ & 0.06 & corundum \\
$\mathrm{Al}_{2} \mathrm{O}_{3}$ & 0.08 & $0.07-0.10$ & 0.02 & 0.02 & b.d.-0.08 & 0.03 & Nb \\
$\mathrm{Nb}_{2} \mathrm{O}_{5}$ & 61.74 & $61.21-62.21$ & 0.43 & 65.79 & $65.22-66.27$ & 0.37 & wollastonite \\
$\mathrm{SiO}_{2}$ & 0.02 & b.d.I.-0.06 & 0.03 & 0.00 & b.d.I.-b.d.I. & 0.00 & \\
$\mathrm{H}_{2} \mathrm{O}$ & 8.35 & & & 8.90 & & &
\end{tabular}

Note: b.d.I. = below detection limits.

1. $\left(\mathrm{Ba}_{1.75} \mathrm{~K}_{0.19}\right)_{\Sigma 1.94}\left(\mathrm{Na}_{1.80} \mathrm{Ca}_{0.19}\right)_{\Sigma 1.99}\left(\mathrm{Mg}_{0.96} \mathrm{Mn}_{0.02} \mathrm{Al}_{0.02}\right)_{\Sigma 1.00} \mathrm{Nb}_{6.02} \mathrm{O}_{19.00} \cdot 6 \mathrm{H}_{2} \mathrm{O}(\mathrm{n}=4)$

2. $\left(\mathrm{Ba}_{0.99} \mathrm{~K}_{1.00}\right)_{\Sigma 1.99}\left(\mathrm{Na}_{1.02} \mathrm{Ca}_{0.96}\right)_{\Sigma 1.98}\left(\mathrm{Mg}_{0.95} \mathrm{Mn}_{0.05}\right)_{\Sigma 1.00} \mathrm{Nb}_{6.02} \mathrm{O}_{19.00} \cdot 6 \mathrm{H}_{2} \mathrm{O}(\mathrm{n}=8)$ 
TABLE 2. X-ray powder diffraction data for melcherite.

\begin{tabular}{|c|c|c|c|c|c|}
\hline$d_{o b s .}(\AA)$ & $d_{\text {calc. }}(\AA)$ & $I_{o b s .}$ & $h$ & $k$ & $l$ \\
\hline 11.337 & 11.705 & 6 & 0 & 0 & 2 \\
\hline \multirow[t]{2}{*}{7.805} & 7.813 & 100 & 0 & 1 & 0 \\
\hline & 7.803 & & 0 & 0 & 3 \\
\hline 7.410 & 7.411 & 14 & 0 & 1 & 1 \\
\hline 6.505 & 6.499 & 7 & 0 & 1 & 2 \\
\hline 5.906 & 5.853 & 6 & 0 & 0 & 4 \\
\hline 4.508 & 4.511 & 10 & 1 & 1 & 0 \\
\hline 4.018 & 4.016 & 8 & 0 & 1 & 5 \\
\hline \multirow[t]{2}{*}{3.904} & 3.907 & 22 & $\mathbf{0}$ & 2 & 0 \\
\hline & 3.905 & & 1 & 1 & 3 \\
\hline 3.852 & 3.853 & 21 & 0 & 2 & 1 \\
\hline \multirow[t]{2}{*}{3.250} & 3.249 & 33 & $\mathbf{0}$ & 2 & 4 \\
\hline & 3.249 & & 1 & 1 & 5 \\
\hline 3.074 & 3.074 & 9 & 0 & 1 & 7 \\
\hline \multirow[t]{2}{*}{2.952} & 2.953 & 13 & 1 & 2 & $\mathbf{0}$ \\
\hline & 2.951 & & 1 & 1 & 6 \\
\hline 2.861 & 2.863 & 8 & 1 & 2 & 2 \\
\hline 2.740 & 2.740 & 8 & 0 & 1 & 8 \\
\hline 2.637 & 2.637 & 8 & 1 & 2 & 4 \\
\hline \multirow[t]{2}{*}{2.243} & 2.245 & 6 & 2 & 2 & 1 \\
\hline & 2.243 & & 0 & 1 & 10 \\
\hline \multirow[t]{2}{*}{2.165} & 2.166 & 30 & $\mathbf{0}$ & 3 & 6 \\
\hline & 2.165 & & 0 & 2 & 9 \\
\hline 2.160 & 2.158 & 12 & 1 & 3 & 1 \\
\hline \multirow[t]{2}{*}{2.078} & 2.079 & 4 & 1 & 2 & 8 \\
\hline & 2.078 & & 1 & 1 & 10 \\
\hline
\end{tabular}

This is a 'preproof' accepted article for Mineralogical Magazine.

This version may be subject to change during the production process. 


\begin{tabular}{|l|l|l|l|l|l|}
\hline 2.053 & 2.055 & 5 & 0 & 3 & 7 \\
\hline & 2.053 & & 0 & 1 & 11 \\
\hline 2.034 & 2.032 & 4 & 1 & 3 & 4 \\
\hline & 2.032 & & 2 & 2 & 5 \\
\hline 1.836 & 1.835 & 4 & 1 & 2 & 10 \\
\hline 1.703 & 1.704 & 5 & 2 & 2 & 9 \\
\hline 1.629 & 1.629 & 4 & 2 & 3 & 6 \\
\hline 1.562 & 1.562 & 5 & 1 & 4 & 6 \\
\hline & 1.562 & & 0 & 4 & 9 \\
\hline
\end{tabular}

This is a 'preproof' accepted article for Mineralogical Magazine.

This version may be subject to change during the production process.

https://10.1180/minmag.2017.081.026 
TABLE 3. Structure refinement results for melcherite.

\begin{tabular}{|c|c|}
\hline Ideal chemical formula & $\mathrm{Ba}_{2} \mathrm{Na}_{2} \mathrm{Mg}\left[\mathrm{Nb}_{6} \mathrm{O}_{19}\right] \cdot 6 \mathrm{H}_{2} \mathrm{O}$ \\
\hline crystal size (mm) & $0.07 \times 0.05 \times 0.05 \mathrm{~mm}$ \\
\hline Space group & $R-3$ \\
\hline$a(\AA)$ & $9.0117(6)$ \\
\hline$c(\AA)$ & $23.3986(16)$ \\
\hline$V\left(\AA^{3}\right)$ & 1645.64(19) \\
\hline$Z$ & 3 \\
\hline$\rho_{\text {cal }}\left(g / \mathrm{cm}^{3}\right)$ & 3.748 \\
\hline$\lambda(\AA)$ & 0.71073 \\
\hline$\mu\left(\mathrm{mm}^{-1}\right)$ & 5.46 \\
\hline $2 \theta$ max. for data collection $\left({ }^{\circ}\right)$ & $\leq 66.38$ \\
\hline No. of reflections collected & 5316 \\
\hline No. of independent reflections & 1403 \\
\hline No. of reflections with $I>2 \sigma(I)$ & 1319 \\
\hline No. of parameters refined & 65 \\
\hline$R_{\text {int }}$ & 0.022 \\
\hline Final $R$ factors $[I>2 \sigma(I)]$ & $R_{1}=0.017, w R_{2}=0.042$ \\
\hline Final $R$ factors (all data) & $R_{1}=0.019, w R_{2}=0.041$ \\
\hline Goodness-of-fit & 1.13 \\
\hline Largest diff. peak and hole & 1.30 and -1.59 e. $\AA^{-3}$ \\
\hline
\end{tabular}
weighting scheme: $w=1 /\left[\sigma^{2}\left(F_{\mathrm{o}}^{2}\right)+(0.0146 P)^{2}+5.6144 P\right]$, where $P=\left[\max \left(0, F_{\mathrm{o}}\right)^{2}+\left(2 F_{\mathrm{c}}\right)^{2}\right] / 3$. 
TABLE 4. Final fractional coordinates and displacement parameters of atoms in melcherite.

\begin{tabular}{|c|c|c|c|c|c|c|c|c|c|c|c|}
\hline Atom & $x$ & $y$ & $z$ & Occ. & $U_{\text {eq }}$ & $U_{11}$ & $U_{22}$ & $U_{33}$ & $U_{23}$ & $U_{13}$ & $U_{12}$ \\
\hline $\mathrm{Ba}$ & 0.6667 & 0.3333 & $0.172426(14)$ & 0.5325 (19) & $0.01366(10)$ & 0.01099 (12) & 0.01099 (12) & $0.01899(16)$ & 0.000 & 0.000 & $0.00550(6)$ \\
\hline K & 0.6667 & 0.3333 & $0.172426(14)$ & 0.4674 (19) & $0.01366(10)$ & 0.01099 (12) & 0.01099 (12) & $0.01899(16)$ & 0.000 & 0.000 & $0.00550(6)$ \\
\hline $\mathrm{Nb}$ & $0.50011(2)$ & $0.58932(2)$ & $0.109104(6)$ & & $0.00677(6)$ & $0.00634(8)$ & $0.00681(9)$ & $0.00773(8)$ & $-0.00028(5)$ & $0.00039(5)$ & $|0.00372(6)|$ \\
\hline $\mathrm{Ca}$ & 0.6667 & 0.3333 & 0.01125 (4) & 0.457 (10) & 0.0101 (3) & 0.0114 (4) & $0.0114(4)$ & $0.0074(5)$ & 0.000 & 0.000 & $0.0057(2)$ \\
\hline $\mathrm{Na}$ & 0.6667 & 0.3333 & 0.01125 (4) & $0.543 \quad(10)$ & 0.0101 (3) & $0.0114(4)$ & $0.0114(4)$ & $0.0074(5)$ & 0.000 & 0.000 & $0.0057(2)$ \\
\hline $\mathrm{Mg}$ & 0.6667 & 0.3333 & 0.3333 & & $0.0111(3)$ & 0.0093 (5) & $0.0093(5)$ & $0.0148(7)$ & 0.000 & 0.000 & $0.0046(2)$ \\
\hline 01 & $0.52940(18)$ & $0.80056(17)$ & $0.06922(6)$ & & $0.0092(2)$ & 0.0085 (6) & $0.0081(6)$ & 0.0110 (6) & 0.0017 (4) & 0.0016 (4) & 0.0042 (5) \\
\hline $\mathrm{O} 2$ & 0.62705 (19) & 0.52389 (19) & 0.06912 (6) & & $0.0140(3)$ & 0.0114 (6) & $0.0130(7)$ & $0.0182(7)$ & $-0.0022(5)$ & 0.0030 (5) & 0.0066 (6) \\
\hline $\mathrm{O} 3$ & 0.66867 (17) & $0.74208(18)$ & 0.16615 (5) & & $0.0099(2)$ & $0.0072(6)$ & $0.0121(6)$ & $0.0103(5)$ & $-0.0021(5)$ & $-0.0006(4)$ & $0.0047(5)$ \\
\hline $\mathrm{O} 4$ & 0.3333 & 0.6667 & 0.1667 & & $0.0081(6)$ & 0.0077 (9) & 0.0077 (9) & 0.0090 (13) & 0.000 & 0.000 & 0.0039 (4) \\
\hline OW5 & 0.2005 (2) & $0.1518(2)$ & $0.05373(8)$ & & 0.0184 (3) & 0.0121 (7) & 0.0107 (7) & 0.0327 (9) & $-0.0050(6)$ & $-0.0064(6)$ & $0.0060(6)$ \\
\hline H51 & $0.229(4)$ & $0.255(2)$ & 0.0579 (13) & & 0.030 & & & & & & \\
\hline H52 & $0.286(3)$ & $0.142(4)$ & 0.0566 (13) & & 0.030 & & & & & & \\
\hline
\end{tabular}


TABLE 5. Selected bond lengths and bond valences of the refined melcherite structure.

\begin{tabular}{|c|c|c|c|}
\hline Bond & Bond length & $B V(v . u)$ & $\Sigma$ \\
\hline$(\mathrm{Ba}, \mathrm{K})-\mathrm{O} 3$ & $2.7189(14)$ & $0.261(x 2)$ & 0.522 \\
\hline$(\mathrm{Ba}, \mathrm{K})-\mathrm{O} 3$ & $2.7190(14)$ & 0.261 & 0.261 \\
\hline$(\mathrm{Ba}, \mathrm{K})-\mathrm{OW} 5$ & $2.9923(18)$ & $0.125(x 3)$ & 0.375 \\
\hline \multirow[t]{2}{*}{$(\mathrm{Ba}, \mathrm{K})-\mathrm{O} 2$} & $3.0875(15)$ & $0.096(x 3)$ & 0.288 \\
\hline & & & 1.446 \\
\hline $\mathrm{Nb}-\mathrm{O} 1$ & $2.0154(13)$ & 0.754 & 0.754 \\
\hline $\mathrm{Nb}-\mathrm{O} 1$ & $2.0161(13)$ & 0.753 & 0.753 \\
\hline $\mathrm{Nb}-\mathrm{O} 2$ & $1.7906(14)$ & 1.385 & 1.385 \\
\hline $\mathrm{Nb}-\mathrm{O} 3$ & $1.9691(13)$ & 0.855 & 0.855 \\
\hline $\mathrm{Nb}-\mathrm{O} 3$ & $1.9731(13)$ & 0.845 & 0.845 \\
\hline \multirow[t]{2}{*}{$\mathrm{Nb}-\mathrm{O} 4$} & $2.3678(2)$ & 0.291 & 0.291 \\
\hline & & & 4.883 \\
\hline$(\mathrm{Na}, \mathrm{Ca})-\mathrm{O} 2$ & $2.3501(15)$ & $0.286(x 3)$ & 0.858 \\
\hline \multirow[t]{2}{*}{$(\mathrm{Na}, \mathrm{Ca})-\mathrm{O} 1$} & $2.4476(15)$ & $0.2203(x 3)$ & 0.660 \\
\hline & & & 1.518 \\
\hline Mg-OW5 & $2.0602(16)$ & 0.371 & 0.371 \\
\hline \multirow[t]{2}{*}{ Mg-OW5 } & $2.0603(16)$ & $0.371(x 5)$ & 1.484 \\
\hline & & & 2.226 \\
\hline O1-Nb & $2.0154(16)$ & 0.754 & 0.754 \\
\hline O1-Nb & $2.0161(16)$ & 0.753 & 0.753 \\
\hline \multirow[t]{2}{*}{ O1-(Na,Ca) } & $2.4476(15)$ & 0.220 & 0.220 \\
\hline & & & 1.727 \\
\hline $\mathrm{O} 2-\mathrm{Nb}$ & $1.7906(14)$ & 1.385 & 1.385 \\
\hline $\mathrm{O} 2-(\mathrm{Na}, \mathrm{Ca})$ & $2.3501(15)$ & 0.286 & 0.286 \\
\hline \multirow[t]{2}{*}{$\mathrm{O} 2-(\mathrm{Ba}, \mathrm{K})$} & $3.0875(15)$ & 0.080 & 0.096 \\
\hline & & & 1.767 \\
\hline O3-Nb & $1.9691(13)$ & 0.855 & 0.855 \\
\hline $\mathrm{O} 3-\mathrm{Nb}$ & $1.9731(13)$ & 0.845 & 0.845 \\
\hline \multirow[t]{2}{*}{ O3-(Ba,K) } & $2.7189(14)$ & 0.261 & 0.261 \\
\hline & & & 1.961 \\
\hline $\mathrm{O} 4-\mathrm{Nb}$ & $2.3678(2)$ & $0.291(\times 6)$ & 1.746 \\
\hline OW5-Mg & $2.0603(16)$ & 0.371 & 0.371 \\
\hline \multirow[t]{2}{*}{ OW5-(Ba,K) } & $2.9923(18)$ & 0.125 & 0.125 \\
\hline & & & 0.496 \\
\hline
\end{tabular}


TABLE 6. Selected interatomic bond lengths $(\AA)$ and octahedral distortion indices for melcherite $\left(\mathrm{Ba}_{2} \mathrm{Na}_{2} \mathrm{MgNb}_{6} \mathrm{O}_{19} \cdot 6 \mathrm{H}_{2} \mathrm{O}\right)$, peterandresenite $\left(\mathrm{Mn}_{4} \mathrm{Nb}_{6} \mathrm{O}_{19} \cdot 14 \mathrm{H}_{2} \mathrm{O}\right)$ and hansesmarkite $\left(\mathrm{Ca}_{2} \mathrm{Mn}_{2} \mathrm{Nb}_{6} \mathrm{O}_{19} \cdot 20 \mathrm{H}_{2} \mathrm{O}\right)$.

\begin{tabular}{|c|c|c|c|c|c|}
\hline & melcherite & & peterandresenite $^{1}$ & & hansesmarkite $^{2}$ \\
\hline Nb-O1 & $2.0154(13)$ & Nb1-O1 & $2.3982(1)$ & Nb1-O1 & $2.3990(6)$ \\
\hline Nb-O1 & 2.0161(13) & Nb1-O2 & $1.7685(8)$ & $\mathrm{Nb} 1-\mathrm{O} 2$ & $1.780(1)$ \\
\hline $\mathrm{Nb}-\mathrm{O} 2$ & $1.7906(14)$ & Nb1-O3 & $1.9767(8)$ & Nb1-O3 & $1.962(1)$ \\
\hline Nb-O3 & 1.9691(13) & Nb1-O4 & $1.9799(6)$ & Nb1-O4 & $1.973(1)$ \\
\hline Nb-O3 & 1.9731(13) & Nb1-O5 & $2.0080(6)$ & Nb1-O5 & $2.020(1)$ \\
\hline Nb-O4 & $2.3678(2)$ & Nb1-O6 & $2.0290(8)$ & Nb1-O6 & $2.034(1)$ \\
\hline Mean & 2.022 & Mean & 2.027 & Mean & 2.028 \\
\hline $\mathrm{OV}^{*}$ & 10.513 & OV & 10.506 & OV & 10.723 \\
\hline OAV & 113.650 & OAV & 132.281 & OAV & 119.622 \\
\hline OQE & 1.040 & OQE & 1.046 & OQE & 1.042 \\
\hline Mg-OW5 & $2.0602(16)$ & Nb2-O1 & $2.3679(1)$ & Nb2-O1 & $2.3576(6)$ \\
\hline Mg-OW5 & $2.0603(16)$ & Nb2-O3 & $1.9716(8)$ & Nb2-O4 & 1.977(1) \\
\hline \multirow[t]{2}{*}{ Mean } & 2.060 & $\mathrm{Nb2-O3}$ & $1.9716(8)$ & Nb2-O5 & $2.029(1)$ \\
\hline & & Nb2-O6 & $2.0208(8)$ & $\mathrm{Nb2-O7}$ & $1.766(1)$ \\
\hline $\mathrm{OV}$ & 11.603 & Nb2-O6 & $2.0208(8)$ & Nb2-O8 & $1.982(1)$ \\
\hline OAV & 12.285 & $\mathrm{Nb2-O7}$ & $1.777(1)$ & Nb2-O9 & $2.019(1)$ \\
\hline OQE & 1.003 & Mean & 2.021 & Mean & 2.021 \\
\hline (Na,Ca)-O2 & 2.3501(15) & OV & 10.522 & OV & 10.714 \\
\hline \multirow[t]{2}{*}{ (Na,Ca)-O1 } & $2.4476(15)$ & OAV & 110.055 & OAV & 108.276 \\
\hline & & OQE & 1.039 & OQE & 1.039 \\
\hline OV & 15.689 & & & & \\
\hline OAV & 354.100 & Mn1-O2 & 2.0645 & Nb3-O1 & $2.3764(6)$ \\
\hline \multirow[t]{19}{*}{ OQE } & 1.113 & Mn1-O2 & 2.0645 & Nb3-O3 & $1.956(1)$ \\
\hline & & Mn1-O5 & 2.220 & Nb3-O6 & $2.033(1)$ \\
\hline & & Mn1-O6 & 2.3250 & Nb3-O8 & 1.979(1) \\
\hline & & Mn1-O6 & 2.3250 & Nb3-O9 & $2.010(1)$ \\
\hline & & Mn1-O8 & $2.253(2)$ & Nb3-10 & $1.785(1)$ \\
\hline & & Mean & 2.208 & Mean & 2.023 \\
\hline & & OV & 13.518 & $\mathrm{OV}$ & 10.691 \\
\hline & & OAV & 146.530 & OAV & 121.348 \\
\hline & & OQE & 1.044 & OQE & 1.044 \\
\hline & & Mn2-O7 & 2.088(1) & Mn-O5 & $2.230(1)$ \\
\hline & & Mn2-O9 & $2.106(2)$ & Mn-O6 & $2.208(1)$ \\
\hline & & Mn2-O10 & $2.237(1)$ & Mn-O7 & $2.050(1)$ \\
\hline & & Mn2- O10 & $2.237(1)$ & Mn-O9 & $2.254(1)$ \\
\hline & & Mn2-O11 & $2.240(1)$ & Mn-O11 & $2.149(2)$ \\
\hline & & Mn2-O11 & $2.240(1)$ & Mn-O12 & $2.180(2)$ \\
\hline & & Mean & 2.191 & Mean & 2.178 \\
\hline & & OV & 13.992 & OV & 13.417 \\
\hline & & OAV & 4.489 & OAV & 104.704 \\
\hline & & OQE & 1.003 & OQE & 1.030 \\
\hline
\end{tabular}

This is a 'preproof' accepted article for Mineralogical Magazine.

This version may be subject to change during the production process. https://10.1180/minmag.2017.081.026 
1: Friis et al. (2014); 2: Friis et al. (2016)

*OV = octahedral volume, $\mathrm{OAV}=$ octahedral angle variance, and $\mathrm{OQE}=$ octahedral quadratic elongation (Robinson et al. 1971). 
TABLE 7. Comparative data for melcherite and synthetic compounds (all trigonal, $R-3$ ).

\begin{tabular}{|l|l|l|l|}
\hline & \multicolumn{2}{|l|}{ chemical formula } & \multicolumn{2}{|l|}{ unit cell parameters ( $\mathrm{A})$} \\
\hline melcherite* $^{*}$ & $\mathrm{Ba}_{2} \mathrm{Na}_{2} \mathrm{Mg}\left[\mathrm{Nb}_{6} \mathrm{O}_{19}\right] .6 \mathrm{H}_{2} \mathrm{O}$ & $a=9.0117(6)$ & $c=23.3986(16)$ \\
\hline synthetic $^{\dagger}$ & $\mathrm{Cs}_{6} \mathrm{Na}_{2}\left(\mathrm{Nb}_{6} \mathrm{O}_{19}\right) \cdot 18\left(\mathrm{H}_{2} \mathrm{O}\right)$ & $a=12.609(2)$ & $c=22.745(5)$ \\
\hline synthetic $^{\dagger}$ & $\mathrm{Rb}_{6}\left(\mathrm{H}_{2} \mathrm{Nb}_{6} \mathrm{O}_{19}\right) \cdot 19\left(\mathrm{H}_{2} \mathrm{O}\right)$ & $a=12.271(2)$ & $c=20.686(3)$ \\
\hline
\end{tabular}

*This work.

${ }^{\dagger}$ Nyman et al. (2006). 
TABLE 8. Comparison of melcherite with other naturally-occurring hexaniobates.

\begin{tabular}{|l|l|l|l|}
\hline Name & melcherite & peterandresenite & hansesmarkite $^{2}$ \\
\hline Formula & $\begin{array}{l}\mathrm{Ba}_{2} \mathrm{Na}_{2} \mathrm{Mg} \\
\mathrm{Nb}_{6} \mathrm{O}_{19} \bullet 6 \mathrm{H}_{2} \mathrm{O}\end{array}$ & $\mathrm{Mn}_{4} \mathrm{Nb}_{6} \mathrm{O}_{19} \bullet 14 \mathrm{H}_{2} \mathrm{O}$ & $\begin{array}{l}\mathrm{Ca}_{2} \mathrm{Mn}_{2} \mathrm{Nb}_{6} \mathrm{O}_{19} \bullet \\
20 \mathrm{H}_{2} \mathrm{O}\end{array}$ \\
\hline Space group & $\mathrm{R}-3$ & $\mathrm{C} 2 / \mathrm{m}$ & $\mathrm{P}-1$ \\
\hline $\mathrm{a}(\AA)$ & $9.0117(6)$ & $15.3444(3)$ & $9.081(4)$ \\
\hline $\mathrm{b}(\AA \AA \AA)$ & $9.0117(6)$ & $9.4158(2)$ & $9.982(8)$ \\
\hline $\mathrm{c}(\AA)$ & $23.3986(16)$ & $11.2858(4)$ & $10.60(1)$ \\
\hline$\alpha\left(\left(^{\circ}\right)\right.$ & 90 & 90 & $111.07(8)$ \\
\hline$ß\left(^{\circ}\right)$ & 90 & $118.632(1)$ & $101.15(6)$ \\
\hline$\gamma\left(^{\circ}\right)$ & 120 & 90 & $99.39(5)$ \\
\hline$Z$ & 3 & 2 & 1 \\
\hline $\mathrm{V}\left(\AA^{3}\right)$ & $1645.64(19)$ & $1431.18(7)$ & $851.5(13)$ \\
\hline $\begin{array}{l}\text { Strongest PXRD } \\
\text { lines d(I) }\end{array}$ & $7.805(100) ; 3.250$ & $2.9260(100) ;$ & $8.610(100) ; 9.282$ \\
& $(33) ; 2.165(30)$ & $9.8977(82) ;$ & $(36) ; 3.257(30)$ \\
\hline Optics & Uniaxial (?) & $7.1026(63)$ & \\
\hline
\end{tabular}

1: Friis et al. (2014); 2: Friis et al. (2016) 